\title{
Toleransi Perspektif KH. M. Hasyim Asy'ari dan Peran Pendidikan Islam Sebagai Upaya Deradikalisasi di Indonesia
}

\author{
Mukani \\ SMA Negeri 1 Jombang Jawa Timur \\ E-mail: mlorah42@gmail.com
}

\begin{abstract}
The diversity value has been an interested discussion in Indonesia. Many groups have made effort to impose their views to be accepted for others that leads to exclusivity and tends to be radical. In this stage, being exclusive to give opinion will be able to be frightening terrorist to society. This article reviews the tolerance (tasamuh) concept initiated by KH. M. Hasyim Asy'ari as an alternative solution as deradicalization effort in Indonesia. This concept is sourced from 23 books and treatises written by Kiai Hasyim. This article positioned the tasamuh concept as pearl when the threat of intolerance has spreaded in this country. The advantage of this concept can be seen the toughness aspect. Kiai Hasyim in this case did not create theory only, he had carried out it consistenly in his daily life. This tasamuh value has been urgently required this nation in spreading the beauty of Islam as rahmatan lil 'alamin religion. Education has an important role in introducing more closely the tasamuh value initiated Kiai Hasyim to society in the life of nation and religion in Indonesia which known as multicultural nation.
\end{abstract}

Keywords: Multicultural, Tolerance, Islamic Education

\section{Pendahuluan}

Beberapa tahun ini di Indonesia banyak terjadi peristiwa kekerasan dan kerusuhan yang mengatasnamankan agama. Ungkapan SARA (suku, agama, ras dan antar golongan) masih selalu menghadirkan konotasi sebagai sesuatu negatif dan sensitif, mudah meledak jika tersentuh. ${ }^{1}$

Hasyim Muzadi menulis bahwa konflik antarumat beragama di Indonesia, sebagai bangsa yang multikultural, setidaknya disebabkan tiga faktor, yaitu pemahaman agama yang parsial, ditunggangi oleh unsur politik-ekonomi dan persoalan non-agama yang diagamakan. ${ }^{2}$

${ }^{1}$ Imam Bawani, Segi-Segi Pendidikan Islam (Surabaya: Al-Ikhlas, 1987), 54.

${ }^{2}$ Hasyim Muzadi, "Menemukan Kembali Nilai Universal Agama" dalam Nazaruddin, Pluralisme Agama (Malang: UIN Maliki, 2010), 176. Pemahaman agama pada masyarakat Indonesia pada umumnya dipahami sebagai sistem kepercayaan, tingkah laku, nilai, pengalaman dan yang terinstitusionalisasi, diorientasikan kepada masalah spiritual dan ritual yang disalingtukarkan dalam sebuah komunitas dan diwariskan antar generasi dalam tradisi. Penegasan yang ingin disampaikan di sini adalah bahwa konsekuensi dari pemahaman keagamaan yang kaku, tidak bersifat scientific justru akan memunculkan stigmatisasi negatif terhadap peran penting agama dalam relasi kemanusiaan. Stigmatisasi tersebut berpandangan bahwa agama identik dengan dogmatism, rigidity, excessive selfblaming dan gender bias, lihat Moh. Toriqul Chaer, "Menjaga Keutuhan Bangsa" (FENOMENA (p-ISSN: 2086-3632, e-ISSN: 2460-3902) is an Islamic Studies Journal published by Center for Research and 
Agama Islam, pada perspektif lain, khususnya dalam setiap kajian keilmuan, selalu dihadapkan kepada kesulitan, terutama dalam usaha memperoleh pemahaman holistik dan terhindar dari pengertian bias. Demikian pula dihadapkan pada adanya kesenjangan (distance) antara pemahaman nilai-nilai Islam dengan realitas kehidupan umat Islam sehari-hari. ${ }^{3}$ Tidak adanya kesinambungan (matching) antara norma Islam yang sangat luhur dengan realitas umat yang tidak Islami seperti ini mendorong berbagai kajian untuk menemukan solusi, terutama dalam membumikan kembali nilai-nilai toleransi (tasamuh) di Indonesia.

Fenomena ini mendorong penulis untuk membaca kembali konsep kebhineka-an yang digagas Hadratussyaikh KH. M. Hasyim Asy'ari (Kiai Hasyim). Pemilihan sosok Kiai Hasyim pada artikel ini didasari fakta bahwa dalam bidang pluralisme beragama.

Nurcholis Madjid berpendapat bahwa pemikiran Kiai Hasyim lebih menunjukkan kepada sebuah kesadaran di antara masyarakat muslim untuk menghormati eksistensi masyarakat lain. Pemikiran Kiai Hasyim tentang pluralisme beragama telah mendorong masyarakat muslim untuk bersikap adil kepada masyarakat lain atas dasar perdamaian dan saling menghormati. Kontribusi pemikiran ini mampu menempatkan nama Kiai Hasyim sejajar dengan Ibnu Taimiyyah, tokoh besar bermadzhab Hambali dari Damaskus Syiria. ${ }^{4}$

Sikap toleransi yang ditunjukkan Kiai Hasyim ini adalah buah dari pengaruh Kiai Saleh Darat Semarang yang sangat kental dalam mengedepankan sikap tasamuh, meskipun akhirnya Kiai Hasyim mendirikan organisasi NU yang tidak menolak tradisi sebagai bagian dari ajaran Islam, sedangkan Ahmad Dahlan (Darwis) kemudian mendirikan organisasi yang mengkritisi dan menolak keberadaan tradisi sebagai sesuatu yang bid'ah (innovation) dan khurafah (superstition). ${ }^{5}$

James J. Fox, antropolog dari Australian National University (ANU), menulis bahwa Kiai Hasyim sebagai salah satu waliyullah yang sangat berpengaruh di pulau

Community Services of IAIN Samarinda, Indonesia, Vol No. l 2016), 2, http://journal.iainsamarinda.ac.id/index.php/fenomena/article/view/542.

${ }^{3}$ Tim MKPK Agama Islam Unesa, Islam Rahmatan lil 'Alamin (Surabaya: Unesa University Press, 2002), xi.

${ }^{4}$ Nurcholis Madjid, Islam, Doktrin dan Peradaban (Jakarta: Paramadina, 1992), 602-604.

${ }^{5}$ Ali Mas'ud, "al-Taqalid al-Islamiyah al-Iqlimiyah bi Indusiya," Journal of Indonesian Islam, Vol. 7 No. 1 (Juni, 2013), 187-211. 
Jawa karena memiliki kedalaman ilmu dan diyakini membawa berkah bagi para pengikutnya. $^{6}$

Howard M. Federspiel, guru besar di McGill University Montreal Kanada, menilai Kiai Hasyim bukan merupakan sosok ulama yang menolak perubahan, tetapi, agaknya, sebagai seseorang yang tertarik kepada perubahan, meskipun hanya di dalam sistem tradisional Islam sendiri. ${ }^{7}$ Keberhasilan Kiai Hasyim dalam mendirikan dan mengembangkan Pesantren Tebuireng Jombang, terlebih organisasi NU, setidaknya telah menunjukkan bahwa keduanya merupakan sebuah upaya untuk merealisasikan pemikirannya, yang disinyalir memiliki akar pertautan dengan perkembangan pembaharuan Islam yang digagas oleh Muhammad 'Abduh di Mesir. 8

Persetujuan Kiai Hasyim dengan bentuk republik di Indonesia, bukan berdasar agama tertentu, menunjukkan perilaku tasamuh yang tinggi, meskipun jasa dan perjuangan besar sudah dilakukan Kiai Hasyim dalam mewujudkan Indonesia merdeka. $^{9}$

Pemikiran-pemikiran Kiai Hasyim, dalam berbagai bidang, menurut Lathiful Khuluq, juga merefleksikan konsep tasamuh, bukan eksklusif. ${ }^{10}$ Amiq bahkan menyandingkan Kiai Hasyim sejajar dengan Sayyid Utsman dalam mendukung revolusi kemerdekaan, dengan menggunakan term jihad untuk melawan Belanda. ${ }^{11}$

Zamakhsyari Dhofier menulis bahwa sosok kiai, secara umum, memiliki tradisi tersendiri dalam menjalankan roda kehidupan, di samping dari segi pandangan hidup kiai itu sendiri. Sedangkan Kiai Hasyim, secara khusus, lebih digambarkan sebagai sosok yang mengikuti tradisi itu, dengan tasamuh sebagai fondasinya, dan merupakan sosok yang konsisten dalam menjaga tradisionalisme

\footnotetext{
${ }^{6}$ Sebagaimana dikutip Muhammad Rifai, KH. Hasyim Asy'ari, Biografi Singkat 1871-1947 (Yogyakarta: Ar-Ruzz, 2009), 36-37.

${ }^{7}$ Howard M. Federspiel, "Kata Pengantar" dalam Lathiful Khuluq, Fajar Kebangunan Ulama (Yogyakarta: LKiS, 2000), xi.

${ }^{8}$ Jeanne S. Mintz, Muhammad, Marx, Marhaen; Akar Sosialisme di Indonesia, terj. Zulhilmiyasari (Yogyakarta: Pustaka Pelajar, 2002), 18

${ }^{9}$ Lathiful Khuluq, "KH. Hasyim Asy'ari Contribution to Indonesian Independence," Jurnal Studia Islamica, No. 1 (1998), 41-67.

${ }^{10}$ Lathiful Khuluq, KH. Hasyim Asy'ari, Religious Thought Political Activities (1871-1947) (Jakarta: Logos, 2000)

${ }^{11}$ Amiq, "Jihad Againts the Dutch Colonization in Indonesia : Studi of the Fatwas of Sayyid Utsman (1822-1913) and KH. Hasyim Asy'ari (1871-1947)," Tesis tidak dipublikasikan (Leiden: Leiden University, 1998).
} 
Islam, tidak teralienasi oleh kolonialisme. ${ }^{12}$ Nurul Hanani menambahkan bahwa, dengan berparadigma tasamuh, terdapat pengaruh signifikan dari pemikiran Kiai Hasyim tentang ijtihad dan taqlid terhadap perkembangan penetapan hukum di NU. ${ }^{13}$

Pola pemikiran dan perilaku yang merefleksikan tasamuh dari Kiai Hasyim dengan baik ditulis Zuhairi Misrawi. ${ }^{14}$ Sifat moderasi ditunjukkan Kiai Hasyim melalui organisasi NU, seraya sudah menancapkan tonggak gerakan moderat yang menggabungkan gagasan keumatan dengan ide kebangsaan. Terlebih, hingga saat ini, NU berada di garda terdepan dalam mengawal Pancasila dan UUD 1945 untuk NKRI. Sedangkan M. Sanusi telah memotret berbagai kebiasaan dari Kiai Hasyim yang mencerminkan sikap tasamuh. ${ }^{15}$

Berbagai karya Kiai Hasyim, secara eksplisit maupun implisit, mengandung berbagai macam pemikiran Kiai Hasyim tentang konsep tasamuh yang perlu dikembangkan masyarakat menuju Indonesia damai. Tidak sekedar mengajar para murid di pesantren, Kiai Hasyim juga menghasilkan puluhan karya bagi pengembangan dunia pendidikan Islam. Berbagai artikel (risalah) yang ditulis menunjukkan respon Kiai Hasyim terhadap berbagai problematika yang sedang dihadapi masyarakat.

Resolusi jihad, sebagai studi kasus, menunjukkan ijtihad Kiai Hasyim yang sangat kreatif dan inovatif dalam membela kepentingan rakyat. Meski menyadari bahwa Indonesia terdiri dari banyak pemeluk agama dan suku, Kiai Hasyim tetap mewajibkan umat Islam untuk berperang melawan penjajah Belanda. Konsep tasamuh sudah diimplementasikan dengan baik oleh Kiai Hasyim.

Pendapat Kiai Hasyim yang berbeda dengan ulama lain juga harus dipandang sebagai sebuah ikhtilafiyah yang wajar di kalangan sesama ahli agama. Sebagai contoh adalah pendapat Kiai Hasyim yang menggunakan bedug di masjid Pesantren Tebuireng. Ini bertentangan dengan pendapat KH. Abdullah Faqih Maskumambang

\footnotetext{
${ }^{12}$ Zamakhsyari Dhofier, "The Pesantren Tradition: A Study of the Role of the Kyai in the Maintenance of the Traditional Ideology of Islam in Java," Disertasi tidak dipublikasikan (Canberra: The Australia National University, 1980).

${ }^{13}$ Nurul Hanani, "Ijtihad dan Taqlid Dalam Perspektif KH. Hasyim Asy'ari," Tesis tidak dipublikasikan (Surabaya: IAIN Sunan Ampel, 2004).

${ }^{14} Z$ uhairi Misrawi, Hadratussyaikh Hasyim Asy'ari, Moderasi, Keumatan dan Kebangsaan (Jakarta: Kompas, 2010).

${ }^{15}$ M. Sanusi, Kebiasaan-kebiasaan Inspiratif KH. Ahmad Dahlan dan KH. Hasyim Asy'ari (Yogyakarta: Diva Press, 2013).
} 
Gresik yang tidak menggunakan bedug di masjid pondoknya, namun menggunakan kentongan. Saat Kiai Hasyim berkunjung ke Maskumambang, kiai yang berbeda pendapat dengan Kiai Hasyim justru memerintahkan kepada pengurus mushalla dan masjid di sekitar Maskumambang untuk "sementara mengganti" kentongan yang ada dengan bedug. ${ }^{16}$ Begitu pula dengan sebaliknya saat kiai tersebut berkunjung ke Tebuireng.

Kasus bedug ini merupakan sebuah bentuk konkrit dari sikap tasamuh Kiai Hasyim. Meskipun keduanya sama-sama dari organisasi NU. ${ }^{17}$ Yang harus ditonjolkan dari kasus ikhtilafiyah ini seharusnya bukan ikhtilafiyah-nya itu sendiri, tetapi sifat kenegarawanan dan legawa Kiai Hasyim dalam merespon perbedaan pendapat melalui diutamakannya sikap tasamuh. Meskipun saat itu Kiai Hasyim menjabat sebagai ra'is akbar NU dan Kiai Faqih adalah wakilnya.

Meski diakui semasa hidup Kiai Hasyim tidak pernah menulis sebuah buku yang utuh dan tebal, tetapi berupa risalah yang membahas tema aktual dalam masyarakat. Namun, risalah yang tipis itu tidak menunjukkan bobot mutu tentang tulisan Kiai Hasyim. Berdasar fakta itu, sangat salah dan naif jika seseorang menilai bahwa kiai diasumsikan dengan orang yang hanya mengajarkan ilmu agama. Kiai Hasyim mampu menunjukkan diri dan mengajarkan bahwa kiai harus memahami Islam secara menyeluruh, termasuk mencintai tanah air dengan sepenuh hati (wathany). Ini bisa dibaca dari berbagai karya Kiai Hasyim, baik dalam bentuk kitab ataupun risalah, yang berjumlah sekitar 20 judul itu. ${ }^{18}$

Artikel ini akan mengeksplorasi konsep tasamuh yang digagas Kiai Hasyim. Tulisan ini menjadikan karya-karya Kiai Hasyim sebagai sumber primer. Penulisan artikel ini menggunakan metode dokumentasi dengan pendekatan library research sebagai ciri khas. Analisis tulisan ini menggunakan pendekatan biografis dan pendekatan arkeologis (archeological approach) perspektif Michel Foucault, yang menyuarakan berbagai hasil pemikiran Kiai Hasyim menjadi sebuah "benda bicara"

\footnotetext{
${ }^{16}$ Abdurrahman Wahid, Islamku Islam Anda Islam Kita (Jakarta: Yayasan Abad Demokrasi, 2011), 256.

${ }^{17}$ Wawancara dengan KH. Fahmi Amrullah, cucu KH. M. Hasyim Asy'ari dan pengasuh Pesantren Tebuireng Putri Jombang, 17 Maret 2015, pukul 08.55 WIB.

${ }^{18}$ Wawancara dengan KH. A. Musta'in Syafi'i, guru senior di Pesantren Tebuireng Jombang, 20 Nopember 2016, pukul 20.21 WIB.
} 
dalam konteks kehidupan sekarang, terutama tentang tasamuh. ${ }^{19}$ Sehingga teks, konteks dan kontekstualisasi, menjadi tiga hal pokok dalam artikel ini. ${ }^{20}$

\section{Sketsa Biografi KH. M. Hasyim Asy'ari}

Kiai Hasyim dilahirkan di dusun Gedang Jombang Jawa Timur pada tanggal 24 Dzulqa'dah 1287 Hijriyah atau 14 Pebruari 1871 Masehi. ${ }^{21}$ Kiai Hasyim lahir dari pasangan Kiai Asy’ari dan Halimah. Nama lengkap Kiai Hasyim adalah Muhammad Hasyim bin Asy'ari bin 'Abdul Wahid bin 'Abdul Halim (Pangeran Benowo) bin 'Abdurrahman (Joko Tingkir atau Mas Karebet atau Sultan Hadiwijaya) bin 'Abdullah bin 'Abdul Aziz bin 'Abdul Fattah bin Maulana Ishaq bin Raden Ainul Yaqin yang lebih populer dengan sebutan Sunan Giri. ${ }^{22}$

Garis keturunan Kiai Hasyim mewakili dua trah sekaligus di Pulau Jawa, yaitu aristokrat dan elit masyarakat Islam. Dari pihak ibu, mata rantai genetis Kiai Hasyim menjadi keturunan langsung dari Prabu Brawijaya VI, raja Majapahit, yang berlatar belakang bangsawan Hindu Jawa. Sedangkan dari jalur ayah, garis keturunan Kiai Hasyim bertemu langsung dengan bangsawan Muslim di pulau Jawa, yaitu Sultan Hadiwijaya dan sekaligus elit agama Islam, yaitu Sunan Giri. Kombinasi kedua garis ini kelak menjadi modal bagi Kiai Hasyim untuk menjadi salah satu pemimpin besar di Indonesia.

Kiai Hasyim adalah putera ketiga dari sebelas bersaudara. Semasa hidup, Kiai Hasyim pernah menikah dengan empat perempuan, yaitu Nyai Khadijah binti Kiai Ya'qub (Sidoarjo), Nafishah binti Kiai Romli (Kediri), Nyai Nafiqah binti Kiai Ilyas (Madiun) dan Nyai Masrurah binti Kiai Hasan Muchyi (Kediri). Namun keempatnya bukan dipoligami, tetapi Kiai Hasyim menikah lagi setelah berstatus duda.

Dengan isteri pertama, Kiai Hasyim memiliki satu putera bernama Abdullah yang meninggal dunia pada usia 40 hari. Dengan isteri kedua, Kiai Hasyim tidak

9.

${ }^{19}$ Michel Foucault, Arkeologi Pengetahuan, terj. Moechtar Zoelmi (Yogyakarta: Qalam, 2002), 5-

${ }^{20}$ Mudjia Raharjo, Dasar-dasar Hermeneutika (Yogyakarta: Ar-Ruzz, 2008), 31.

${ }^{21}$ Achmad Muhibbin Zuhri, Pemikiran KH. M. Hasyim Asy'ari tentang Ahlus Sunnah wal Jama'ah (Surabaya: Khalista, 2010), 67. Baca juga Choirul Anam, Pertumbuhan dan Perkembangan Nahdlatul Ulama (Solo: Jatayu, 1985), 56-58 dan Abdul Basit Adnan, Kemelut di NU, Antara Kyai dan Politisi (Solo: Mayasari, 1982), 31-32.

${ }^{22}$ Muhammad Isham Hadziq, "al-Ta'rif bil Mu'allif," dalam Muhammad Hasyim Asy'ari, Ziyadatut Ta'liqat (Jombang: Maktabah al-Turats al-Islamy, 1995), 3 dan Adabul 'Alim wal Muta'allim, 3. 
memiliki putera dan dengan isteri ketiga Kiai Hasyim memiliki 10 anak, yaitu Hannah, Khairiyah (Ummu Abdul Jabbar), Aisyah (Ummu Muhammad), Azzah (Ummu Abdul Haq), Abdul Wahid, Abdul Hakim (Kiai Khaliq), Abdul Karim, Ubaidillah, Masrurah dan Muhammad Yusuf. Sedangkan dengan isteri terakhir, Kiai Hasyim memiliki empat putera, yaitu Abdul Qadir, Fathimah, Khadijah dan Muhammad Ya'qub.

Kiai Hasyim adalah sosok yang tidak mengenal kata menyerah dalam menimba ilmu. Setelah lima tahun berada dalam pendidikan dan lingkungan kakeknya di Pesantren Gedang, dilanjutkan dengan 10 tahun dalam pola pendidikan ayahnya di Pesantren Keras Jombang, Kiai Hasyim memberanikan diri pamit kepada orang tuanya untuk mencari ilmu di Pesantren Wonorejo Jombang, Pesantren Wonokoyo Probolinggo dan Pesantren Lagitan Tuban. ${ }^{23}$ Kemudian melanjutkan ke Pesantren Tenggilis Surabaya, Pesantren Kademangan Bangkalan Madura dan Pesantren Siwalan Panji Sidoarjo.

Setelah menikah, satu tahun berikutnya Kiai Hasyim bersama isteri dan mertuanya berangkat ke Mekkah untuk melaksanakan ibadah haji dan menimba ilmu di sana selama tujuh tahun. Di antara guru Kiai Hasyim di Arab Saudi adalah Syaikh Mahfuz al-Tirmisi, Syaikh Ahmad Khatib al-Minankabawi, Syaikh Nawawi al-Bantani, Syaikh Ahmad Amin al-Aththar, Sayyid Sulthan bin Hasyim, Sayyid Ahmad Nawawi, Syaikh Ibrahim 'Arb, Sayyid Ahmad bin Hasan al-Aththasy, Syaikh Sa'id al-Yamani, Sayyid Abu Bakar Syatha’ al-Dimyati, Syaikh Rahmatullah, Sayyid 'Alwi bin Ahmad al-Saqaf, Sayyid 'Abbas Maliki, Sayyid 'Abdullah al-Zawawi, Syaikh Shalih Bafadhal, Syaikh Syu'aib bin Abdurrahman, Syaikh Sulthan Hasyim Daghastani dan Sayyid Husain al-Habsyi yang saat itu menjadi mufti di Mekkah. ${ }^{24}$

Melihat prestasi belajar Kiai Hasyim yang menonjol, membuatnya kemudian memperoleh kepercayaan untuk mengajar di Masjidil Haram Mekkah. Beberapa ulama terkenal dari berbagai negara pernah belajar kepadanya, seperti Syaikh Sa'dullah al-Maymani (India), Syaikh Umar Hamdan (Mekkah), al-Syihab Ahmad bin 'Abdullah (Syiria), KH. Abdul Wahab Hasbullah (Tambakberas), KH. Asnawi

\footnotetext{
${ }^{23}$ Zamakhsyari Dhofier, Tradisi Pesantren (Jakarta: LP3ES, 1982), 24; Akarhanaf, Kiai Hasjim Asj'ari, Bapak Ummat Islam Indonesia (Jombang: Pondok Tebuireng, 1950), 22; Solichin Salam, KH. Hasyim Asy'ari, Ulama Besar Indonesia (Jakarta: Djaja Murni, 1963), 23.

${ }^{24}$ Muhammad Asad Syihab, Hadratussyaikh Muhammad Hasyim Asy'ari, terj. A. Musthofa Bisri (Yogyakarta: Titian Ilahi, 1994), 4l; Zuhri, Pemikiran KH. M. Hasyim Asy'ari, 76.
} 
(Kudus), KH. Bisyri Syansuri (Denanyar), KH. Dahlan (Kudus) dan KH. Saleh (Tayu). ${ }^{25}$

Pada tahun 1883, Kiai Hasyim kembali ke rumah orang tuanya di Jombang untuk mengajarkan berbagai ilmu yang telah diperolehnya di Mekkah. Di samping juga mengajar di pesantren mertuanya di Kediri dan pesantren kakeknya di Gedang Jombang. Dengan memiliki setting sebagai orang 'alim, Kiai Hasyim kemudian menjadi salah satu guru yang terkenal di Jombang. Oleh karena itu, Kiai Hasyim berkeinginan mendirikan pesantren sendiri dalam rangka mendukung upaya dakwah yang telah dilakukan para kiai sebelumnya. Maka, dipilihlah suatu daerah untuk mendirikan sebuah pesantren baru, yaitu Tebuireng.

Pesantren Tebuireng berdiri pada 26 Rabi'ul Awwal 1317 Hijriyah (1899 Masehi) dan diakui Belanda pada 6 Pebruari 1907 Masehi. Selama kurang lebih dua setengah tahun, Kiai Hasyim bersama delapan santrinya harus berjuang untuk menjaga eksistensi Pesantren Tebuireng dari segala serangan, fitnah, gangguan dan sebagainya yang berasal dari tokoh-tokoh "dunia hitam" di sekitar pabrik gula Tjoekir tersebut. Namun ketinggian moralitas yang ditunjukkan Kiai Hasyim merupakan daya tarik tersendiri dalam menaklukkan kerasnya mental masyarakat Tebuireng saat itu. Kesabaran Kiai Hasyim dalam mewujudkan gagasannya, termasuk tidak menggunakan kekerasan dalam berdakwah, telah menyebabkan masyarakat yang menentang upaya Kiai Hasyim menjadi lelah untuk melawan terus menerus dan akhirnya pun mereka menghentikan aksinya. Ini yang menjadi entry point dari dakwah Kiai Hasyim yang sukses di tempat baru tersebut.

Pesantren Tebuireng telah mengalami berbagai perubahan, meskipun tokoh sentral di pesantren tersebut masih Kiai Hasyim sendiri. Sikap terbuka terhadap perubahan dalam memimpin institusi pendidikan yang ditunjukkan Kiai Hasyim merupakan pengaruh dari setting sosial politik yang terjadi di kawasan Arab. Ini dapat dilihat dari persetujuan Kiai Hasyim terhadap gagasan dan realisasinya dari KH. Ma'shum 'Ali, santrinya sendiri yang sekaligus menjadi menantu, yang memperkenalkan sistem madrasah di lingkungan pesantren. Gagasan ini direalisasikan untuk semakin meningkatkan kualitas output pesantren melalui pemantauan terhadap kehadiran santri dalam mengikuti proses belajar mengajar

${ }^{25}$ Zuhri, Pemikiran KH. M. Hasyim Asy'ari, 76; Zuhairi Misrawi, Hadratussyaikh Hasyim Asy'ari, 49. 
yang dilakukan kyai (sistemisasi manajemen). Contoh lain adalah sikap terbuka Kiai Hasyim terhadap pengajaran mata pelajaran umum di Madrasah Tebuireng tersebut, seperti matematika, geografi, sejarah, menulis huruf Latin dan bahasa Belanda. ${ }^{26}$

Bersama para kiai lain, pada 21 Januari 1926 di Surabaya, Kiai Hasyim mendirikan organisasi Nahdlatul Ulama' (NU). Sampai dengan 1933, dengan menduduki jabatan sebagai Rais Akbar, peran Kiai Hasyim memang sangat diperlukan bagi pertumbuhan organisasi ini, termasuk juga meredam konflik antara kaum Islam modernis dengan kaum Islam tradisional yang bermuara kepada masalah perbedaan pendapat antara keduanya tentang masalah-masalah furu'iyyah. Pidato Kiai Hasyim di Muktamar NU ketiga pada tanggal 28-30 Oktober 1928 di Surabaya, telah dijadikan NU sebagai pengantar dari Anggaran Dasar (Al-2anun Al-Asasi) organisasi ini. ${ }^{27}$ Sedangkan pidato Kiai Hasyim di Muktamar NU tahun 1936 di Banjarmasin yang mengomentari konflik antara Islam modernis dengan Islam tradisionalis yang semakin meruncing, memperoleh respon positif dari kaum Islam modernis, bahkan diterjemahkan sendiri oleh seorang tokoh Islam modernis (Hamka) dan dimuat di Pandji Masjarakat, sebuah majalah yang sering memuat ideologi-ideologi pembaruan.

Saat penjajahan Jepang, pemerintah militer mengetahui peran penting Kiai Hasyim ini. Bagi Jepang, ketokohan dan popularitas yang dimiliki Kiai Hasyim harus dikelola dengan baik untuk kepentingan kolonial di Indonesia. Atas alasan itu, Jepang kemudian mengangkat Kiai Hasyim sebagai Shumobutyo, sebuah jabatan yang memimpin Kantor Urusan Agama Pusat di Jakarta. ${ }^{28}$ Bahkan, menjelang proklamasi kemerdekaan NKRI pada 17 Agustus 1945, Maruto Nitimiharjo ditugasi pemerintah militer Jepang untuk menemui Kiai Hasyim di Pesantren Tebuireng agar bersedia menjadi Presiden RI. Tawaran itu ditolak oleh Kiai Hasyim yang mengatakan bahwa dia hanya seorang kiai yang tugasnya adalah mendidik santri di pesantren.

Saat ditanya sosok yang layak untuk menjadi Presiden RI, Kiai Hasyim menjawab bahwa yang tepat menjadi presiden adalah Bung Karno dan wakilnya adalah Bung Hatta. Meski Jepang sebenarnya sudah tahu jika tawaran itu akan

\footnotetext{
${ }^{26}$ Baca Dhofier, Tradisi Pesantren, 104; Adnan, Kemelut di NU, 33; Karel A. Steenbrink, Pesantren, Madrasah dan Sekolah (Jakarta: LP3ES, 1974), 70-71.

${ }^{27}$ Lihat Anam, Ibid, 74-83; Adnan, Kemelut di NU, 13-17.

${ }^{28}$ Misrawi, Hadratussyaikh Hasyim Asy'ari, 55.
} 
ditolak, namun penugasan Nitimiharjo ini menunjukkan pengakuan dari Jepang terhadap peran strategis dari Kiai Hasyim. Untuk itu, jawaban yang disampaikan Kiai Hasyim tentang sosok yang didukung sangat diperlukan Jepang sangat berarti dan penting. ${ }^{29}$

Meskipun demikian, hasil kemerdekaan ternyata belum dinikmati Kiai Hasyim dengan lama. Kiai Hasyim wafat pada 25 Juli 1947 M. atau 7 Ramadhan 1366 H karena mengalami pendarahan otak (hersenbloeding) setelah mendengar kabar terakhir dari Kiai Ghufran bersama dua orang utusan Bung Tomo tentang kekalahan Pasukan Sabilillah dan Hizbullah di Singosari (Malang), akibat serangan besar-besaran yang dilakukan tentara Belanda di bawah pimpinan Jenderal S.H. Spoor.

Jenasah Kiai Hasyim dimakamkan di kompleks pemakaman keluarga Pesantren Tebuireng. Atas jasa-jasa Kiai Hasyim dalam mendirikan dan membela Indonesia, pemerintah menganugerahi Kiai Hasyim dengan gelar Pahlawan Pergerakan Nasional. Penetapan ini berdasarkan Surat Keputusan Presiden Republik Indonesia Nomor 249/1964 tanggal 17 Nopember 1964.

Semasa hidup, Kiai Hasyim merupakan salah satu ulama penulis yang produktif. Tulisan-tulisan tersebut berbahasa Arab dan Jawa, baik terkait masalah 'aqidah, fiqh, hadits, tashawuf, pendidikan maupun lainnya. Mayoritas artikel (risalah) yang ditulis menunjukkan respon Kiai Hasyim terhadap problematika yang dihadapi masyarakat. Di antara tulisan-tulisan Kiai Hasyim tersebut adalah Adabul 'Alim wal Muta'allim, Al-Nurul Mubin, At-Tanbihat wal Wajibat, Al-Durarul Muntatsirah, Al-Tibyan, AlMawa'idz, Risalah Ahlissunnah wal Jama'ah, Dha'ul Mishbah, Ziyadatut Ta'liqat, Al-Qanun AlAsasi Li Jam'iyyatin Nahdhatil 'Ulama, Arba'in Haditsah, Al-Risalah fil 'Aqa'id, Al-Risalah fil Tashawwuf, Tamyizul Haqq minal Bathil, Al-Risalah fi Ta'kidil Akhdz bi Ahadil Madzahib alA'immah al-Arba'ah, Irsyadus Sari, Hasyiyah 'ala Fathur Rahman, Al-Risalah Al-Tawhidiyyah, Al-Qala'id, Al-Risalah Al-Jama'ah, Manasik Sughra, Al-Jasus fi Ahkamin Nuqush dan sebagainya. ${ }^{30}$

\footnotetext{
${ }^{29}$ Salahuddin Wahid, "Hadratussyaikh, Komitmen Keumatan dan Kebangsaan," dalam Misrawi, Hadratussyaikh Hasyim Asy’ari, xiii-xxii.

${ }^{30}$ Data diolah dari Muhammad Isham Hadziq, "At-Ta'rif bil Mu'allif" dalam Idem, Adabul 'Alim wal Muta'allim, 6-7; Khuluq, Fajar Kebangunan Ulama, 41-43; Zuhri, Pemikiran KH. M. Hasyim Asy'ari, 85-91; Misrawi, Hadratussyaikh Hasyim Asy'ari, 96-99.
} 


\section{Film Sang Kiai}

Peran penting Kiai Hasyim dalam perjuangan menuju Indonesia merdeka, Rapi Films membuat film berjudul Sang Kyai. Film ini pertama kali diputar $30 \mathrm{Mei}$ 2013. Film ini akhirnya terpilih menjadi film bioskop terbaik tahun 2013. Dengan produser Gope T. Samtani dan sutradara Rako Prijanto, film ini dibintangi Ikranagara, Christine Hakim dan Agus Kuncoro.

Film drama religi ini juga menggandeng aktor-aktor muda. Seperti Adipati Dolken, Dimas Aditya, Royhan Hidayat, Meriza Febriani Batubara, Ernestan Samudra dan Dayat Simbaia. Group band Ungu, sebagai pengisi soundtrack film, memberikan dua buah lagu, Asmara Terindah dan Bila Tiba.

Pengambilan lokasi shooting film ini mayoritas di Kediri. Namun separoh lebih adegan diambil di Pesantren Salafiyah Kapurejo Pagu. Ini tidak berlebihan mengingat setting film itu adalah menjelang proklamasi 1945. Itu berarti Kiai Hasyim didampingi oleh Nyai Masrurah, putri pendiri Pesantren Salafiyah Kapurejo, KH. Hasan Muchyi. Di Jawa Timur, pemutaran film Sang Kyai di bioskop seolah menjadi oase kecil dari membludaknya film kurang bermutu yang diputar selama ini. Film ini launching dilakukan di bioskop Citos Surabaya pada 30 Mei 2013 silam.

Secara gradual, diangkatnya sosok Kiai Hasyim dalam sebuah cerita film menjadi kemajuan tersendiri. Kakek mantan presiden Gus Dur ini tidak hanya diakui sebagai tokoh agama Islam tradisional. Tapi juga tokoh pergerakan yang menginginkan Indonesia merdeka sejak dulu.

Film Sang Kyai rupanya ingin menampilkan Kiai Hasyim sebagai sosok inisiator Resolusi Jihad yang dicetuskan pada 22 Oktober 1945. Di film itu, Resolusi Jihad adalah jawaban NU yang dimotori Kiai Hasyim terhadap pertanyaan Bung Karno tentang hukum orang Islam yang berjuang demi bangsanya, bukan karena Tuhannya. $^{31}$

Di satu sisi, masih banyak hal yang belum terungkap dalam penulisan sejarah pertempuran paling bersejarah dari arek-arek Surabaya saat itu. Ketidakseimbangan penulisan sejarah ini menjadi hal lumrah, mengingat penulisan sejarah sangat dipengaruhi sumber yang digunakan (from), faktor penulis (by) dan konsumen dari

${ }^{31}$ A. Aziz Masyhuri, 99 Kiai Pondok Pesantren Nusantara (Yogyakarta: Kutub, 2006), 298-300. 
dokumentasi sejarah (for) itu sendiri. Masih sangat minim tulisan yang mengkaji peran NU dalam Pertempuran Surabaya. Teks-teks sejarah lebih memprioritaskan kepada peran militer ketika melawan Belanda dan NICA. Tapi peran laskar Hizbullah dan Sabilillah belum memperoleh perhatian secara proporsional. Keduanya adalah laskar sipil yang dibentuk NU untuk melawan kolonialisme.

Padahal, fakta sejarah menulis, tepat 22 Oktober 1945, para kiai NU berkumpul di Kantor PB Anshor, Jln. Bubutan VI No. 2 Surabaya guna mengeluarkan Resolusi Jihad. Secara global, resolusi ini mewajibkan kepada seluruh umat Islam dalam jarak 94 kilometer untuk mengangkat senjata. Berperang melawan tentara Belanda hukumnya fardhu 'ain. Para pejuang yang gugur nanti dihukumi sebagai mati syahid.

Oleh NU, lima butir Resolusi jihad ini lalu disahkan dalam Muktamar NU XVI di Purwokerto tanggal 26-29 Maret 1946. Menurut Lathiful Khuluq, dalam artikel KH. Hasyim Asy'ari's Contribution to Indonesia Independence, resolusi ini digambarkan sebagai kontribusi besar NU bagi mempertahankan Indonesia merdeka. Artikel ini juga dipandang sebagai lembaran penting dari sejarah revolusi fisik Indonesia yang jarang sekali mencantumkan keterlibatan ulama' dan tokoh agama.

Tokoh sentral di balik Resolusi Jihad tersebut adalah Kiai Hasyim. ${ }^{32}$ Tidak heran jika kalangan pesantren di Jawa Timur sangat antusias mematuhi resolusi itu dengan cara mengirim santrinya untuk berperang melawan Belanda di Surabaya. Di bagian selatan, para santri berkumpul di mushalla al-Falah, yang sekarang menjadi masjid, depan Kebon Binatang Surabaya (KBS). Sektor barat berkumpul di daerah Gunungsari, bahkan dipimpin langsung oleh Muhammad Yusuf Hasyim, putera bungsu Kiai Hasyim.

Konon, sebelum berangkat ke Surabaya, para santri ini dibekali oleh para kiai sepuh Jombang dengan biji kacang hijau dan jagung yang sudah dibacakan doa-doa khusus. Alhasil, butiran biji-bijian tersebut saat dilemparkan berubah seketika menjadi senjata mematikan bagi tentara Belanda. Biji kacang hijau setelah dilempar

${ }^{32}$ Zainul Milal Bizawie, Laskar Ulama-Santri dan Resolusi Jihad (Jakarta: Kompas, 2014), 3. 
menjadi peluru senapan. Sedangkan biji jagung berubah menjadi granat setelah dilempar. Akhirnya, kekuatan tentara Belanda kocar-kacir. ${ }^{33}$

Fatwa Resolusi Jihad ini terbukti ampuh untuk memobilisasi umat Islam di Surabaya dan sekitarnya. Bahkan, dalam film Sang Kyai dilukiskan, para santri dari Jombang berbondong-bondong memenuhi panggilan jihad fi sabilillah ini. Terutama dari laskar Hizbullah dan Sabilillah. Kedua barisan pejuang ini dibentuk NU untuk mempertahankan kemerdekaan Indonesia. Tidak berselang lama, meletus Perang Arek-arek Suroboyo 10 Nopember 1945 yang sangat heroik itu.

Film berdurasi 135 menit ini sudah selayaknya dinikmati kaum muda di negeri ini. Setidaknya sudah ada film bernuansa nasionalisme religius di tengah gempuran film tidak bermutu yang hanya menyuguhkan roman picisan dan aksi kekerasan. $^{34}$

Nilai-nilai karakter pun akan didapat dengan mudah dari fim ini. Mulai patriotisme, nasionalisme, kejujuran, keikhlasan, religius, konsistensi sampai advokasi kepada kaum tertindas. Film Sang Kyai setidaknya adalah "pengingat" bahwa masih banyak nama pahlawan yang belum tertulis dalam sejarah bangsa ini. Meski sebenarnya hal itu tidak begitu penting. Karena, sebagaimana pernyataan Kiai Hasyim yang dikutip untuk closing statement dalam film itu, setiap orang yang berjuang bagi bangsa hakikatnya adalah pahlawan. Tidak peduli namanya telah ditulis dalam buku sejarah atau belum.

\section{Tasamuh Moderat}

Deskripsi konsep tasamuh menurut pemikiran Kiai Hasyim merupakan dimensi menarik untuk dikaji. Hal ini didasarkan kepada banyaknya tulisan Kiai Hasyim yang berkaitan dengan tema tasamuh, baik secara langsung maupun tidak langsung. Pembahasan di bagian ini berupaya melakukan sistemisasi terhadap dimensi luas ini, dengan diawali penelaahan secara mendalam dan filosofis terhadap karya-karya yang telah disusun. Dengan demikian, pembahasan ini diharapkan

\footnotetext{
${ }^{33}$ Mukani, "Peran NU Pada Pertempuran 10 Nopember 1945," Radar Surabaya, 10 Nopember 2010,8 .

${ }^{34}$ Nurul Yani, "Segalanya Tentang Mbah Hasyim," Majalah Suara Pendidikan, Nopember 2013, 46-47.
} 
mampu memaparkan pemikiran tasamuh Kiai Hasyim secara deskriptif dan komprehensif.

Bukti konkrit tasamuh yang ditunjukkan Kiai Hasyim adalah ketika anak administrator Pabrik Gula (PG) Tjoekir sedang sakit keras, yang notabene adalah orang Belanda beragama Kristen. Dokter dan banyak dukun sudah diundang untuk menyembuhkan dan gagal. Kiai Hasyim pun dimintai tolong dan hanya dengan media air putih, anak tersebut akhirnya sembuh. Administrator pun heran dan ingin mengetahui lebih dekat rahasia "kesaktian" Kiai Hasyim. Beberapa hari kemudian administrator datang ke Pesantren Tebuireng dan ditemui Kiai Hasyim penuh keakraban. Dialog di antara keduanya pun terjadi beberapa kali.

Lambat laun administrator akhirnya memahami ajaran Islam yang harus menghormati dan menolong umat lain, meski berbeda agama. Keterbukaan Islam dalam memandang the others ini mendorong administrator berkeyakinan untuk pindah agama, masuk ke dalam Islam.

Setelah menyelesaikan masa tugas di PG Tjoekir, administrator kembali ke negeri Belanda. Anak-anaknya pun ikut memeluk agama Islam. Bahkan korespondensi melalui surat tertulis terus dilakukan oleh anak cucu administrator dengan KH. Yusuf Hasyim, pengasuh Pesantren Tebuireng antara 1965-2006. ${ }^{35}$

Hal ini dikarenakan Kiai Hasyim memiliki wawasan luas dalam berinteraksi sosial, sebagaimana orang-orang sebelumnya. Sejak dahulu kala, menurut Kiai Hasyim, di tanah pulau Jawa sudah terdapat kecocokan dalam pandangan antar para ulama. Mereka semua dalam bidang fiqih berpedoman kepada pemikiran Imam Muhammad bin Idris al-Syafi'i, dalam bidang 'aqidah mengikuti pendapat Imam Abu Hasan al-Asy'ari, dalam bidang tashawuf mengikuti pemikiran Imam al-Ghazali dan Imam Abu Hasan al-Syadzili. ${ }^{36}$

Namun perbedaan pendapat mulai terjadi sekitar tahun 1330 hijriyah saat ada golongan khalaf yang mengharamkan amalan-amalan ulama salaf. Golongan ini mengikuti pendapat Muhammad Abduh, Rasyid Ridha, Muhammad bin Abdul Wahab, Ahmad bin Taimiyah, Ibnu al-Qayyim dan Ibnu Abdul Hadi. Parahnya lagi

\footnotetext{
${ }^{35}$ Muhammad Asad Syihab, Hadratussyaikh Muhammad Hasyim Asy'ari; Perintis Kemerdekaan Indonesia, terj. A. Musthofa Bisri (Yogyakarta: Titian Ilahi, 1994), 47.

${ }^{36}$ Muhammad Hasyim Asy'ari, Risalah Ahlissunnah wal Jama'ah (Jombang: Maktabah al-Turats al-Islamy, 1998), 9-10.
} 
golongan ini menganggap ulama salaf adalah golongan sesat yang harus dijauhi dan tidak diikuti. Sehingga sikap tasamuh yang sudah dibangun sejak dulu, mulai terkikis dengan keberadaan kelompok eksklusif ini.

Di sisi lain, secara substantif, sebenarnya inti perkara dari agama Islam itu hanya ada tiga. Yaitu mengikuti perintah Allah, menjauhi larangan-Nya dan berpasrah diri terhadap qadha' dan qadar. ${ }^{37}$ Fakta ini menyimpulkan bahwa kehadiran manusia dalam semesta ini setidaknya memiliki dua tugas yang harus dilaksanakan secara seimbang, yaitu dalam kaitan kedudukannya sebagai ciptaan Tuhan ('abdullah) dan manusia juga merupakan ciptaan Tuhan yang bertanggung jawab terhadap kelestarian semesta disekelilingnya (khalifah fil ardhi).

Manusia merupakan sosok penuh potensi (fithrah) yang dibawa sejak dilahirkan ke dunia. Pribadi dengan segala "keunikan" inilah yang mendorong banyak ahli untuk mengungkap misteri yang terdapat di dalamnya. Meskipun demikian, generalisasi dalam proses tersebut tetap dilakukan, yaitu bahwa manusia memiliki yang sama ketika baru dilahirkan. Hal ini, menurut Kiai Hasyim, memiliki implikasi bahwa dalam kehidupan tidak dibenarkan jika ada unsur diskriminasi dalam berinteraksi sosial. ${ }^{38}$

Kiai Hasyim menyeru agar kaum muslim bersaudara dalam urusan kebaikan dan tolong menolong, berpegang teguh kepada agama Allah Swt, yaitu Islam, tidak terpecah-belah, mengikuti ajaran al-Qur'an dan hadits, sebagaimana hal ini telah ditetapkan para ulama salafus shalih. ${ }^{39}$ Dalam konteks interaksi dengan orang lain, hal ini berimplikasi kepada berbagai upaya untuk mempererat persatuan dan kesatuan di antara sesama anggota masyarakat muslim. ${ }^{40}$ Upaya ini perlu ditekankan untuk membangkitkan kembali semangat masyarakat muslim dalam meraih supremasi dunia internasional.

Pengalaman sejarah peradaban Islam telah mengajarkan bahwa fanatisme terhadap golongan sendiri (ta'ashub) yang terjadi di masyarakat muslim pada Periode Pertengahan hanya akan mengakibatkan perpecahan dan kekalahan ketika harus

\footnotetext{
${ }^{37}$ Muhammad Hasyim Asy'ari, Hadzihi al-Risalah Jami'ah al-Maqashid (Jombang: Maktabah alTurats al-Islamy, tt.), 4.

${ }^{38}$ Muhammad Hasyim Asy'ari, al-Tanbihat wal Wajibat (Jombang: Maktabah al-Turats alIslamy, $1417 \mathrm{H}), 36-37$.

${ }^{39}$ Ibid, 15.

${ }^{40}$ Tentang pemikiran Kiai Hasyim dalam hal ini, baca "Al-Mawa'idz" dalam Al-Tibyan.
} 
berhadapan dengan bangsa-bangsa Barat. Namun fenomena yang terjadi ketika Kiai Hasyim masih hidup justru menunjukkan sebaliknya. Masyarakat muslim terkotakkotak ke dalam berbagai kelompok aliran. Oleh karena itu, Kiai Hasyim sangat menekankan persatuan dan kesatuan sesama masyarakat muslim sebagai "modal awal" dalam berjuang melawan kolonialisme.

Persatuan dan kesatuan tersebut tentu harus dijaga dengan baik dan tetap memperhatikan norma yang berlaku di masyarakat. ${ }^{41}$ Hal ini penting untuk ditekankan mengingat manusia adalah homo social yang eksistensinya sangat dipengaruhi oleh kesuksesannya dalam menjalin interaksi dengan manusia lain. Manusia tidak akan mampu kebutuhan hidup hanya dengan dirinya sendiri. Dalam keadaan apapun, manusia pasti masih tetap membutuhkan bantuan orang lain. Baik senang atau susah, kaya atau miskin, pandai atau bodoh. Oleh karena itu, dalam kehidupan sehari-hari manusia harus saling menghormati dan saling menyayangi di antara sesama.

Di sisi lain, praktek interaksi sosial dan realisasi berbagai ritual dalam doktrin Islam yang telah ditunjukkan pada periode Nabi Muhammad Saw sebenarnya merupakan refleksi dari hakikat ajaran Islam yang sebenarnya. Hal ini membawa implikasi kepada sebuah keharusan untuk meneladani segala hal yang telah dilakukan Nabi Saw dalam menjelaskan doktrin Islam. ${ }^{42}$ Dengan demikian, diharapkan Nabi Saw sebagai sosok sempurna dan telah berhasil mengekang nafsu kebinatangannya dijadikan public figure yang kepribadiaannya harus ditiru muslim, baik dari sisi perbuatan ataupun perkataan. Hal ini sesuai dengan firman Allah Swt dalam QS. al-Ahzab: 21 yang menyatakan bahwa dalam diri Nabi Muhammad Saw terdapat suri teladan.

Kehadiran Islam, menurut Kiai Hasyim, tidak hanya berupaya membentuk manusia yang berakidah monoteis (tauhid). Namun juga memajukan aspek sosial, politik dan ekonomi suatu masyarakat yang masih terbelakang. Selain itu, Islam juga berupaya memupuk semangat persaudaraan Islam dengan menghilangkan segala perbedaan yang disebabkan oleh faktor nasab, kekayaan, jabatan ataupun etnisitas. Dengan itu semua, diharapkan dapat terbangun fondasi demokrasi yang sangat

\footnotetext{
${ }^{41}$ Muhammad Hasyim Asy'ari, al-Tibyan (Jombang: Maktabah al-Turats al-Islamy, 1998), 9.

${ }^{42}$ Muhammad Hasyim Asy'ari, al-Nur al-Mubin (Jombang: Maktabah al-Turats al-Islamy, 1998), 16.
} 
menghargai humanisme, sebagaimana telah diperkenalkan pada peradaban Islam pada periode awal.

Lingkungan masyarakat, menurut Kiai Hasyim, menekankan agar seorang muslim berinteraksi dengan anggota masyarakat lain, mengingat manusia adalah homo social yang pasti membutuhkan bantuan pihak lain, tidak bisa hidup dengan diri sendiri. ${ }^{43}$ Manusia merupakan anggota masyarakat yang memiliki peran dan kontribusi besar dalam menjaga eksistensi interaksinya dengan anggota masyarakat lain, yang dengan itu semua dapat mewujud menjadi sebuah kesatuan kuat. Dengan itu semua, maka yang menjadi tujuan bersama suatu masyarakat akan dengan mudah tercapai. Berbagai halangan dan rintangan dapat diatasi dengan mudah jika persatuan dan kesatuan dapat terjaga dengan baik.

Membangun masjid, sebagai studi kasus, menurut Kiai Hasyim, harus tetap menomorsatukan persaudaraan sesama umat Islam. Artinya, pembangunan masjid tidak boleh sampai memecah belah persaudaraan umat Islam dalam suatu kawasan. Jika memang tidak sependapat dengan keabsahan sebuah shalat Jumat, Kiai Hasyim mendorong muslim untuk melaksanakan shalat Jumat di masjid luar desanya. ${ }^{44}$

Jika hal ini tidak dilaksanakan, dikhawatirkan seorang muslim memiliki pola pikir sempit dan pada akhirnya hanya melahirkan fanatisme (ta'ashub) yang sebenarnya tidak diperlukan. ${ }^{45}$ Fanatisme buta ini yang, jika tidak mampu diminimalisasi keberadaannya, akan mengakibatkan perpecahan dalam masyarakat.

Kiai Hasyim sangat mengecam berbagai bentuk fanatisme yang dilakukan mayoritas ulama ketika itu, yang dimunculkan karena hanya masalah furu'iyah, bukan masalah substantif (ushuliyah). Menurut Kiai Hasyim, fanatisme seharusnya merupakan refleksi dari rasa nasionalisme dan ukhuwah Islamiyah dalam merespon berbagai bentuk kolonialisme yang melanda di kawasan-kawasan muslim. Oleh karena itu, sebenarnya tidak diperlukan fanatisme dalam bentuk kepercayaan yang berlebihan terhadap pendapat ulama fiqh, mengingat yang terjadi saat itu bukan

\footnotetext{
${ }^{43}$ Muhammad Hasyim Asy'ari, al-Tibyan, 9.

${ }^{44}$ Muhammad Hasyim Asy'ari, "Risalah fil Masjid," dalam al-Tibyan, 15.

${ }^{45}$ Tentang pandangan Kiai Hasyim terhadap urgensi persatuan dan kesatuan sesama muslim ini, baca al-Mawa'idz dan al-Qanun al-Asasy.
} 
merupakan masalah ushuliyah. Hal ini sudah diuraikan Kiai Hasyim dalam al-Mawa'idz berikut ini: ${ }^{46}$

Wahai para ulama...perbedaan pendapat di antara kalian jangan sampai dijadikan alat untuk permusuhan dan perpecahan. Jika kalian melihat seseorang yang mengamalkan sebuah perbuatan dengan dalil taqlid dari seorang imam madzhab, bukan tempatnya orang itu kamu jadikan musuh. Jika kamu tidak setuju, ingatkan dan tunjukkan dia secara halus...Wahai kaum muslim...bersatulah, tolong menolonglah dalam kebaikan dan ketakwaan, karena kebahagiaan akan semakin jauh bagi kita selama kita masih terus bermusuhan. Padahal kita beragama satu Islam, bermadzhab satu Syafi'i, bertempat tinggal satu di pulau Jawa dan beraliran satu Ahlussunnah wal Jama'ah.

Perbedaan dalam masalah-masalah furu'iyah seperti ini yang telah terbukti memecahkan umat Islam menjadi banyak kelompok. Padahal, menurut Kiai Hasyim, perbedaan pendapat itu jika dikelola dengan baik, akan berdampak positif bagi umat. Hal ini telah ditegaskan Kiai Hasyim dalam kitab Ziyadah Ta'liqat berikut ini: ${ }^{47}$

Perbedaan pendapat di kalangan umat Islam sebenarnya adalah rahmat dan nikmat. Bagi orang-orang berilmu, ini akan dipahami sebagai hal yang penuh rahasia. Namun bagi orang yang bodoh, ini menjadi ujian buta yang penuh kegelapan.

Perbedaan pendapat juga dapat diminimalisasi oleh sikap egaliter. Artinya, semua manusia memiliki kedudukan yang sama di dunia ini. Hal ini dibuktikan Kiai Hasyim saat mendirikan organisasi NU. Semua umat Islam, dengan berbagai macam profesi dan status sosial yang disandang, diperkenankan untuk menjadi anggota dari organisasi yang berdiri pada tahun 1926 itu. Hal ini bisa dipahami dari tulisan Kiai Hasyim dalam al-Qanun al-Asasy berikut ini: ${ }^{48}$

Saya menghimbau dan menganjurkan Anda semua dan juga segenap pengikut Anda dari golongan para fakir miskin, para hartawan, rakyat jelata dan orangorang yang kuat (penguasa), agar berbondong-bondong masuk ke jam'iyah yang diberi nama Nahdlatul Ulama' ini. Masuklah kalian semua dengan penuh kecintaan, kasih sayang, rukun, bersatu dan dengan ikatan jiwa raga. Jam'iyah Nahdlatul Ulama' ini adalah jam'iyah yang lurus, damai dan bersifat memperbaiki dan menyantuni.

\footnotetext{
${ }^{46}$ Muhammad Hasyim Asy'ari, al-Mawa'idz, 34-35.

${ }^{47}$ Muhammad Hasyim Asy'ari, Ziyadah al-Ta'liqat (Jombang: Maktabah al-Turats al-Islamy, 1995), 91 . 1998), 25.

${ }^{48}$ Muhammad Hasyim Asy'ari, al-Qanun al-Asasy (Jombang: Maktabah al-Turats al-Islamy,
} 
Tidak sekedar berteori, selama masih hidup, berbagai contoh sudah ditunjukkan Kiai Hasyim tentang perlunya sifat egaliter. Bergelut di dunia perdagangan sebagai salah satu contohnya. Setiap hari Pon, Kiai Hasyim pergi ke Pasar Pon yang berada di timur stasiun Jombang. Di pasar tradisional itu, Kiai Hasyim menjual hasil beternak kuda dan berbagai macam hasil pertanian dari sawah yang dimiliki. ${ }^{49}$ Meskipun Kiai Hasyim saat itu sudah menjadi seorang ulama besar yang namanya sangat terkenal di Nusantara.

Sikap toleran yang ditunjukkan Kiai Hasyim ini merupakan buah dari pengaruh Kiai Saleh Darat Semarang. Semasa menimba ilmu kepada tokoh ini, Kiai Hasyim semasa dengan Darwis muda yang kelak mendirikan organisasi Muhammadiyah. Pengaruh Kiai Saleh Darat sangat kental dalam mengedepankan sikap tasamuh, meskipun akhirnya Kiai Hasyim mendirikan organisasi NU yang tidak menolak tradisi sebagai bagian dari ajaran Islam, sedangkan Ahmad Dahlan (Darwis) kemudian mendirikan organisasi yang mengkritisi dan menolak keberadaan tradisi sebagai sesuatu yang bid'ah (innovation) dan khurafah (superstition). ${ }^{50}$

\section{Catatan Akhir}

Konsep tasamuh Kiai Hasyim di atas menjadi mutiara yang ditemukan lagi di tengah ancaman intoleran yang mulai menyebar di Indonesia. Kelebihan konsep yang digagas Kiai Hasyim ini adalah aspek keterujian. Artinya, Kiai Hasyim tidak sekedar memunculkan teori, namun juga sudah melaksanakannya secara nyata dan konsisten dalam kehidupan. Nilai-nilai tasamuh yang digagas Kiai Hasyim sangat dibutuhkan bangsa ini dalam menyebarluaskan keindahan Islam sebagai agama yang rahmatan lil 'alamin.

Konsep tasamuh perspektif Kiai Hasyim, dalam konteks kehidupan berbangsa dan bernegara, merupakan solusi konkrit dari semakin carut marutnya persatuan bangsa, karena gempuran globalisasi dan individualisme yang tidak bisa terelakkan. Para pemimpin di negeri ini sudah sepatutnya berkaca dan menggali kembali ide-ide besar yang telah digagas para founding fathers negeri ini. Termasuk dalam menggali

\footnotetext{
${ }^{49}$ Gunseikanbu, Orang Indonesia yang Terkemuka di Jawa (Yogyakarta: Gajah Mada University Press, 1986), 435.

${ }^{50}$ Ali Mas'ud, “al-Taqalid al-Islamiyah al-Iqlimiyah bi Indusiya,” 187-211.
} 
nilai-nilai tasamuh, sehingga tidak mudah "latah" dengan mengadopsi konsep-konsep dari para pemikir luar negeri.

Pada posisi ini, peran pendidikan Islam menjadi sangat penting dalam membumikan nilai-nilai tasamuh yang digagas Kiai Hasyim ke dalam kehidupan berbangsa dan beragama di Indonesia yang terkenal sebagai bangsa multikulural. Peran pendidikan Islam di Indonesia semakin menemukan titik urgensinya ketika dipahami bahwa fungsinya tidak hanya transfer of knowledge, namu juga transfer of values. Toleransi (tasamuh) merupakan nilai luhur bangsa ini yang sudah semestinya diwarikan kepada generasi penerus.*

\section{Daftar Rujukan}

Asy'ari, Muhammad Hasyim. Risalah Ahlissunnah wal Jama'ah. Jombang: Maktabah alTurats al-Islamy, 1998.

. Hadzihi al-Risalah Jami'ah al-Maqashid. Jombang: Maktabah al-Turats al-Islamy, tt.

al-Tanbihat wal Wajibat. Jombang: Maktabah al-Turats al-Islamy, $1417 \mathrm{H}$.

. al-Tibyan. Jombang: Maktabah al-Turats al-Islamy, 1998.

. al-Nur al-Mubin. Jombang: Maktabah al-Turats al-Islamy, 1998.

. al-Mawa'idz. Jombang: Maktabah al-Turats al-Islamy, 1998.

. Ziyadah al-Ta'liqat. Jombang: Maktabah al-Turats al-Islamy, 1995.

al-2anun al-Asasy. Jombang: Maktabah al-Turats al-Islamy, 1998.

. Adabul 'Alim wal Muta'allim. Jombang: Maktabah al-Turats al-Islamy, 1998.

Adnan, Abdul Basit. Kemelut di NU, Antara Kyai dan Politisi. Solo: Mayasari, 1982.

Akarhanaf. Kiai Hasjim Asj'ari, Bapak Ummat Islam Indonesia. Jombang: Pondok Tebuireng, 1950.

Amiq. "Jihad Againts the Dutch Colonization in Indonesia: Studi of the Fatwas of Sayyid Utsman (1822-1913) and KH. Hasyim Asy'ari (1871-1947).” Tesis tidak dipublikasikan. Leiden: Leiden University, 1998.

Anam, Choirul. Pertumbuhan dan Perkembangan Nahdlatul Ulama. Solo: Jatayu, 1985.

Bawani, Bawani. Segi-Segi Pendidikan Islam. Surabaya: Al-Ikhlas, 1987.

Bizawie, Zainul Milal. Laskar Ulama-Santri dan Resolusi Jihad. Jakarta: Kompas, 2014.

Chaer, Moh. Toriqul. "Menjaga Keutuhan Bangsa." FENOMENA (p-ISSN: 20863632, e-ISSN: 2460-3902) is an Islamic Studies Journal published by Center for Research and Community Services of IAIN Samarinda, Indonesia, Vol No. $\quad 112016.2$ http://journal.iainsamarinda.ac.id/index.php/fenomena/article/view/542.

Dhofier, Zamakhsyari. Tradisi Pesantren. Jakarta: LP3ES, 1982.

"The Pesantren Tradition: A Study of the Role of the Kyai in the Maintenance of the Traditional Ideology of Islam in Java." Disertasi tidak dipublikasikan. Canberra: The Australia National University, 1980. 
Federspiel, Howard M. "Kata Pengantar" dalam Lathiful Khuluq, Fajar Kebangunan Ulama. Yogyakarta: LKiS, 2000.

Foucault, Michel. Arkeologi Pengetahuan, terj. Moechtar Zoelmi. Yogyakarta: Qalam, 2002.

Gunseikanbu. Orang Indonesia yang Terkemuka di Jawa. Yogyakarta: Gajah Mada University Press, 1986.

Hadziq, Muhammad Isham. "al-Ta'rif bil Mu'allif," dalam Muhammad Hasyim Asy'ari, Ziyadatut Ta'liqat. Jombang: Maktabah al-Turats al-Islamy, 1995.

Hanani, Nurul. "Ijtihad dan Taqlid Dalam Perspektif KH. Hasyim Asy'ari." Tesis tidak dipublikasikan. Surabaya: IAIN Sunan Ampel, 2004.

KH. Fahmi Amrullah, cucu KH. M. Hasyim Asy'ari, wawancara pribadi. 17 Maret 2015.

KH. A. Musta'in Syafi'i, guru senior di Pesantren Tebuireng Jombang, wawancara pribadi. 20 Nopember 2016.

Khuluq, Lathiful. "KH. Hasyim Asy'ari Contribution to Indonesian Independence," Jurnal Studia Islamica, No. 1 (1998).

. KH. Hasyim Asy'ari, Religious Thought Political Activities (1871-1947). Jakarta: Logos, 2000.

Madjid, Nurcholis. Islam, Doktrin dan Peradaban. Jakarta: Paramadina, 1992.

Mas'ud, Ali. "al-Taqalid al-Islamiyah al-Iqlimiyah bi Indusiya," Journal of Indonesian Islam, Vol. 7 No. 1 (Juni, 2013).

Masyhuri, A. Aziz. 99 Kiai Pondok Pesantren Nusantara. Yogyakarta: Kutub, 2006.

Mintz, Jeanne S. Muhammad, Marx, Marhaen; Akar Sosialisme di Indonesia, terj. Zulhilmiyasari. Yogyakarta: Pustaka Pelajar, 2002.

Misrawi, Zuhairi. Hadratussyaikh Hasyim Asy'ari, Moderasi, Keumatan dan Kebangsaan. Jakarta: Kompas, 2010.

Mukani, "Peran NU Pada Pertempuran 10 Nopember 1945." Radar Surabaya, 10 Nopember 2010.

Muzadi, Hasyim. "Menemukan Kembali Nilai Universal Agama" dalam Nazaruddin, Pluralisme Agama. Malang: UIN Maliki, 2010.

Raharjo, Mudjia. Dasar-dasar Hermeneutika. Yogyakarta: Ar-Ruzz, 2008.

Rifai, Muhammad. KH. Hasyim Asy'ari, Biografi Singkat 1871-1947. Yogyakarta: Ar-Ruzz, 2009.

Salam, Solichin. KH. Hasyim Asy'ari, Ulama Besar Indonesia. Jakarta: Djaja Murni, 1963.

Sanusi, M. Kebiasaan-kebiasaan Inspiratif KH. Ahmad Dahlan dan KH. Hasyim Asy'ari. Yogyakarta: Diva Press, 2013.

Steenbrink, Karel A. Pesantren, Madrasah dan Sekolah. Jakarta: LP3ES, 1974.

Syihab, Muhammad Asad. Hadratussyaikh Muhammad Hasyim Asy'ari; Perintis Kemerdekaan Indonesia, terj. A. Musthofa Bisri. Yogyakarta: Titian Ilahi, 1994.

Tim MKPK Agama Islam Unesa. Islam Rahmatan lil 'Alamin. Surabaya: Unesa University Press, 2002.

Wahid, Abdurrahman. Islamku Islam Anda Islam Kita. Jakarta: Yayasan Abad Demokrasi, 2011.

Wahid, Salahuddin. "Hadratussyaikh, Komitmen Keumatan dan Kebangsaan." Dalam Zuhairi Misrawi. Hadratussyaikh Hasyim Asy'ari, Moderasi, Keumatan dan Kebangsaan. Jakarta: Kompas, 2010. 
Yani, Nurul. "Segalanya Tentang Mbah Hasyim.” Majalah Suara Pendidikan, Nopember 2013.

Zuhri, Achmad Muhibbin. Pemikiran KH. M. Hasyim Asy'ari tentang Ahlus Sunnah wal Jama'ah. Surabaya: Khalista, 2010. 